\title{
Thermal Analysis Evaluation of the Reactivity of Coal Mixtures for Injection in the Blast Furnace
}

\author{
Maria de Lourdes Ilha Gomes, Eduardo Osório*, Antônio Cezar Faria Vilela* \\ Iron and Steelmaking Research Group/LASID, Federal University of Rio Grande do Sul - UFRGS, \\ Technology Center, Av. Bento Gonçalves, 9500, P.O. Box 15021, \\ 91501-970 Porto Alegre - RS, Brazil
}

Received: December 2, 2004; Revised: December 6, 2005

\begin{abstract}
Pulverized Coal Injection (PCI) is an important standard technology replacing coke partially by pulverized coal into the blast furnace that allows a significant reduction of hot metal costs and environmental impact, contributing to a decrease of coke requirements for ironmaking. Coals typically used in this process in Brazil are, at current time, exclusively imported from many countries, although economic important coal-measures occur in the southern part of the country. The Brazilian coals have a low rank, higher contents of inert components, proportioning nocoking properties and an expected high reactivity. Due to these caractheristics, these coals could be used for injection in the blast furnaces in order to decrease the dependency on high cost imported coals. The efficiency in the combustion and the coal reactivity are considered important parameters in the blast furnace, since a larger amount of char (unburned coal) causes severe problems to the furnace operation. The aim of the present work is to compare the reactivity of a south Brazilian coal, obtained from Faxinal mine, with two imported coals and the blends of the Brazilian coal with the imported ones. The reactivity of these coals and their blends were evaluated in a thermogravimetric analyzer. In the experiments, various mass ratios of Faxinal coal and the imported coals were used to compose the blends. The gasification reaction with pure $\mathrm{CO}_{2}$ was conducted under isothermal conditions at $1050{ }^{\circ} \mathrm{C}$ and atmospheric pressure. The experimental results show the greater reactivity of the Faxinal coal. The additive behavior was confirmed. The blends with a composition of up to $50 \%$ Faxinal coal have parameters according to the usual limits used for PCI.
\end{abstract}

Keywords: pulverized coal injection, coal blends, reactivity and thermobalance

\section{Introduction}

Blast furnaces produce the raw material (pig iron) for almost $80 \%$ of the worldwide steel production. The pulverized coal injection in the tuyeres of the blast furnace process (PCI) has enabled an effective increase in the blast furnace productivity due to the diminished consumption of coke, which in Brazil is entirely imported and accounts for most costs in the pig iron production ${ }^{1,2}$.

The coals typically used for pulverized coal injection into the blast furnace tuyeres (PCI) in Brazil are at current time exclusively imported from many countries, although economic important coalmeasures occur in the southern part of the country.

With a production in the order of 5 Millions of tons/year, the principal use for the coal mined in Rio Grande do Sul is the combustion for power generation. This subbituminous coal has a low rank, and high contents of inert components, proportioning nocoking properties and an expected high reactivity. Due to these caractheristics, the south Brazilian coals could be used for injection in the blast furnaces in order to decrease the dependency on high cost imported coals ${ }^{3}$.

However, one of the main problems which prevent the utilization of these coals in PCI are their high mineral matter and sulphur contents. Because of these restrictions, one mode of utilization can be in coal blends with imported coals used for injection.

The efficiency in the combustion is important in the blast furnace, since a larger amount of char (unburned coal) causes severe problems, such as reduced permeability, undesirable gas/temperature distribution and significant char carryover. The more reactive a char is, the better is the effect in the replacement of coke $\mathrm{e}^{4-6}$.
There is not an agreement about the most suitable coal to be injected in the blast furnace, especially in larger injection rates and modified systems. However, the reasonable flexibility of the PCI process allows an expansion of the types of coals to be used, mainly as mixtures, since the sum of the coals' properties will fulfill the process requirements and will guarantee its stability.

The thermogravimetric analysis - TGA - has been widely used to study the combustion behavior of coal and $\operatorname{char}^{7,8}$. The probability of unburned coal particles (char) to react and undergo gasification somewhere in the blast furnace may be estimated in TGA experiments?

The present work aims to evaluate the reactivity of a Brazilian coal (Faxinal mine), imported coals and their mixtures, in different mass ratios, by thermal analysis. Moreover, it intends to demonstrate that the use of mixtures minimizes the negative effect of some properties of the Brazilian coal.

\section{Materials and Methods}

\subsection{Raw materials and sample preparation}

The Brazilian coal sample tested comes from the I- 1 and I- 2 coal beds from the Faxinal mine (Rio Grande do Sul State), owned by Copelmi Mineradora S.A. The ash content in the raw coal $(50 \% \mathrm{w} / \mathrm{w})$ is reduced to $17 \%$ by gravity preparation in a jig.

Two high-rank, low-ash imported coals, identified as A and B, were used to compose the mixtures. The USIMINAS Company donated these samples. 
For the coal samples preparation, Faxinal coal and the A coal were combined in the following mass ratios:

- $75 \%$ Faxinal - 25\% coal A;

- 50\% Faxinal - 50\% coal A; and

- $25 \%$ Faxinal - $75 \%$ coal A.

Similar proportions of Faxinal and B coals were assembled. Samples were comminuted to a particle size $100 \%$ passing the 200 -mesh Tyler sieve and then mixed and homogenized.

\section{Experimental Procedures}

\subsection{Coal characterization}

The tests applied to the characterization of coal and mixtures, described in ${ }^{10}$, were the following:

- Ultimate Analysis: Indicates the coal's chemical composition as hydrogen, carbon, nitrogen, oxygen and sulfur;

- Proximate Analysis: Consists of the moisture content determination, volatile matter, ashes and fixed carbon (by difference). Results are usually expressed in a dry basis;

- Grindability Index: The grindability index or HGI (Hardgrove Grindability Index) determines how grindable a coal is, when compared to standard coals;

- Petrography Analysis: Classifies the coal in a scientific basis, describes constituents and determines its properties (ISO 1994,1995). Petrography is analyzed with the reflected light microscope;

- Analysis of Maceral Groups (Vitrinite, Liptinite and Inertinite): Aims at to determine the macerals proportion in the coal;

- Reflectance of Vitrinite: Indicates the coal carbonification degree or rank;

- Chemical Composition of Ashes (X ray fluorescence): Expresses the concentration of the elements present in the ash as oxides; and

- Particle Size Measurements by Laser Diffraction: The size of the particles is cumulatively evaluated by the diffraction of a laser beam in a dispersion of sample in water and ethanol.

Coal samples were quartered and ground (first in an impact Mill and after in a mortar) until $100 \%$ of the mass passed through a 200mesh sieve $(<75 \mu \mathrm{m})$.

\subsection{Reactivity determination}

A NETZCH - STA 409 thermobalance was used for the analysis accomplishment. It is a fixed-bed differential reactor that operates under the atmospheric pressure and allows the gas-solid reactions to be monitored by the mass variation of the sample with the time.

The platecrucible is the most adequate to the experiments, in the conditions of the analysis, that are: $30 \mathrm{mg}$ of sample and flow of reactant and carrier gases: $50 \mathrm{~mL} / \mathrm{min} \mathrm{N}_{2}$ and $50 \mathrm{~mL} / \mathrm{min} \mathrm{CO}_{2}$ in the gasification. Under such experimental conditions, the resistance due to the stagnant gaseous film around the particle becomes neglectable in relation to the overall resistance of the process.

During the analysis, the following routine was adopted: in the first part of the test (pyrolysis) the samples $(30 \mathrm{mg}$ ) are heated up to $1050{ }^{\circ} \mathrm{C}$, with a $30 \mathrm{~K} / \mathrm{min}$ heating rate, under a flow of $\mathrm{N}_{2}$ $(50 \mathrm{~mL} / \mathrm{min})$; this temperature was kept until the end of the loss of the volatile matter. After the mass stabilization, the reactivity test started, with the replacement of $\mathrm{N}_{2}$ by $\mathrm{CO}_{2}(50 \mathrm{~mL} / \mathrm{min})$, until a new value of stable mass was reached. Each sample was analyzed in duplicate.

Figure 1 shows a graphical evolution of a thermogravimetric analysis. Point 1 indicates the effect of buoyancy force in the beginning of the test and point 2 the beginning of pyrolysis with $\mathrm{N}_{2}$. The point 3 indicates the beginning of the gasification reaction with the injection of $\mathrm{CO}_{2}$ and the mass here corresponds to the initial mass of the devolatilized sample. It can be observed in this figure that the end of the reaction is considered when the stabilization of the sample mass takes place (4).

From the curves of weight loss as a function of time, the conversion was calculated. The conversion is presented in a dry and ash-free basis $^{11-14}$, where $\mathrm{X}$ is the conversion, $\mathrm{W}$ is the char weight of fixed carbon loss and $\mathrm{W}_{0}$ the initial char weight:

$$
\mathrm{X}=1-\frac{\mathrm{W}}{\mathrm{W}_{0}}
$$

Reactivity is defined as the rate at which the char reacts in an oxidizing/reducing atmosphere, subsequently its devolatilization, describing the easiness with that the char reacts with the gasificant agent.

The reaction rate is defined in different ways that are interrelated between themselves and that are independent of the system, but depending on the reactants' properties ${ }^{15}$. The reaction rate can be expressed in a general form, in the case of solid-fluid systems ${ }^{11-14}$ where $r_{A}$ is the maximum reactivity, $W_{o}$ is the initial weight ash free and $(\mathrm{dw} / \mathrm{dt})$ the maximum rate of fixed carbon loss:

$$
\mathrm{r}_{\mathrm{A}}=\frac{1}{\mathrm{~W}_{\mathrm{o}}} \frac{\mathrm{dW}}{\mathrm{dt}}
$$

\section{Results and Discussion}

\subsection{Coal characterization}

Results of sample characterization of the three studied coals (Faxinal, A and B) in relation to ultimate and proximate analyses and HGI are presented in Table 1.

Comparing the values of volatile matter, it is evidenced that the content in Faxinal coal is nearly $50 \%$ higher than those of the imported coals. It happens due to its lower carbonification degree.

In relation to the desired ash content for PCI, coals A and B fall within the range, while Faxinal coal presents a higher value. The sulfur present in the coal accounts for the formation of slag. PCI requirements demand a value close to $1 \%{ }^{4}$. Again, the sulphur content for the Brazilian coal is superior to the recommended and the imported coals show contents around $0.5 \%-0.6 \%$.

The comparison of the values from the ultimate analysis reveals higher values of carbon and hydrogen for the Faxinal coal than for coals A and B. This is due to the difference in their degrees of carbonification. The contents of carbon and hydrogen are often used in the correlation between physical and chemical properties as the

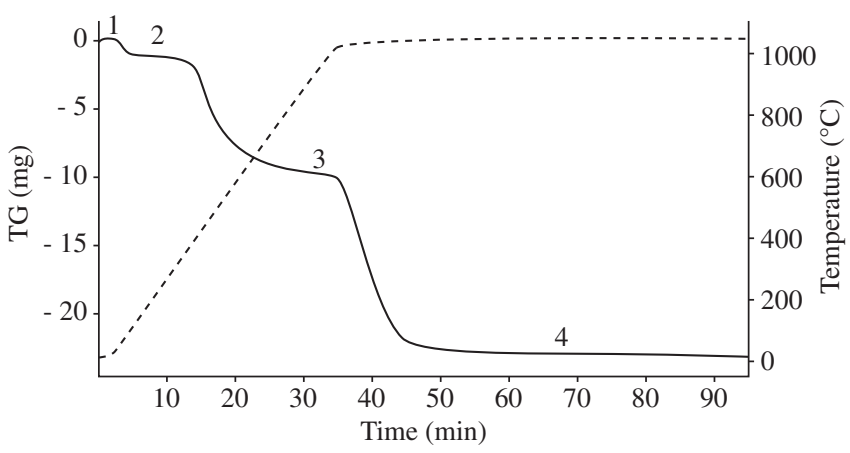

Figure 1. Graphical evolution of the thermogravimetric analysis. 
Table 1. Proximate (volatile matter, ashes and fixed carbon) and ultimate analysis (carbon, hydrogen, total sulfur, halogens, nitrogen and oxygen-by difference), in dry basis (db) for Faxinal, A and B coals.

\begin{tabular}{lccccccccc}
\hline Sample & $\mathrm{VM}_{\mathrm{db}}(\%)$ & $\mathrm{A}_{\mathrm{db}}(\%)$ & $\mathrm{Cfix}_{\mathrm{db}}(\%)$ & $\mathrm{C}_{\mathrm{db}}(\%)$ & $\mathrm{H}_{\mathrm{db}}(\%)$ & $\mathrm{S}_{\mathrm{Tdb}}(\%)$ & $\mathrm{N}_{\mathrm{db}}(\%)$ & $\mathrm{O}+\mathrm{Hal}_{\mathrm{db}}(\%)$ & HGI \\
\hline Faxinal & 33.10 & 17.00 & 49.90 & 66.00 & 4.28 & 1.30 & 1.29 & 10.13 & 58 \\
Coal A & 14.36 & 6.91 & 78.79 & 84.10 & 4.02 & 0.49 & 1.73 & 2.95 & 85 \\
Coal B & 14.68 & 7.61 & 77.71 & 81.20 & 3.82 & 0.67 & 1.73 & 4.41 & 85 \\
\hline
\end{tabular}

$\mathrm{db}=$ dry basis; $\mathrm{T}=$ total

reactivity in the gasification. Nitrogen occurs combined with the coal chemical structure and its values are used to evaluate the potential of the nitrogen oxides formation, causes of atmospheric pollution. In this study, all coals presented a content inferior to $1.5 \%$.

The results of proximate analysis for the coal blends assembled are presented in Table 2 .

The contents of volatile matter for the coal blends is around $20 \%$ and $30 \%$, and these values fall within the range used in the steelmaking industry $(10 \%-40 \%)^{1}$. Very high contents of volatile matter increase the gas volumes and yield unstable combustion and coke degradation ${ }^{4}$.

The reduction in the content of ashes is a very important aspect, both for coals injected in the blast furnace and for the ones used in the power generation. In both cases, the higher the ash content, the greater the consumption of heat will be. In PCI, the carbon consumption and the gas flow can be increased, and the productivity can decrease. The assembly of coal mixtures aimed to reduce the ash contents to around $10 \%$, which is the common value in PCI. It was verified that the mixtures that contained 50\% Faxinal and 50\% Coal A or $50 \%$ Coal B produced sufficiently satisfactory results, very close to the average of the individual coals ash contents. This reveals that mixtures with 50\% Faxinal coal present an acceptable ash content for use in PCI.

The Faxinal coal grindability index - HGI value was 50, while the imported coals presented a value of 85 . The higher HGI values, the greater easiness of milling a determined coal and the lower the costs in this operation. Coals commonly used in PCI present HGI superior to $50^{4}$.

The result of the evaluation of the particle size distribution for the individual coals showed that the diameter of $90 \%$ of the particles is in the 64.52-73.19 $\mu \mathrm{m}$ range. Most of the particles present a diameter close to $75 \mu \mathrm{m}$. Since the particle size distribution is a feature that affects the reaction rate ${ }^{16}$, it is important that all samples present the distributions as close as possible, so that the results are comparative.

Table 3 presents the result of the ashes' chemical composition for the studied coals. Initially the acid nature, typical of ashes from $\mathrm{RS}$ coals, can be observed, with a high content of $\mathrm{SiO}_{2}$. Moreover, one notices that the alkali total value $\left(\mathrm{Na}_{2} \mathrm{O}\right.$ and $\left.\mathrm{K}_{2} \mathrm{O}\right)$ for the Faxinal coal is inferior to those of the imported coals. The presence of alkalis in the coal must be controlled, since to the recirculation of these compounds inside the blast furnace causes an increased coke consumption and the crusts formation.

In relation to phosphorus, the content for the Faxinal coal is much lower than those for the imported coals. Nevertheless, this number falls within the suitable range for $\mathrm{PCI}^{1}$.

The petrography analysis (Table 4) was done at the Laboratory of Coal and Organic Petrology - UFRGS. The Faxinal coals present a high vitrinite content, as well as low vitrinite reflectance, features that are characteristics of the sub bituminous rank of this coal. For the low-volatile bituminous-type coals A and B, the high value for the vitrinite reflectance and the high content of inertinite are recorded.
Table 2. Coal mixtures proximate analysis (moisture, volatile matter, ash and fixed carbon), in dry basis.

\begin{tabular}{clcrc}
\hline Sample & $\begin{array}{c}\text { Moist } \\
(\%)\end{array}$ & \multicolumn{1}{c}{$\begin{array}{c}\mathrm{VM}_{\mathrm{db}} \\
(\%)\end{array}$} & $\begin{array}{c}\mathrm{Ash}_{\mathrm{db}} \\
(\%)\end{array}$ & $\begin{array}{c}\text { C fix } \\
(\%)\end{array}$ \\
\hline Faxinal 75\%-coal A 25\% & 7.254 & 28.07 & 13.43 & 51.25 \\
Faxinal 50\%-coal A 50\% & 0.99 & 23.32 & 10.94 & 60.75 \\
Faxinal 25\%-coal A 75\% & 3.30 & 18.28 & 9.08 & 69.34 \\
Faxinal 75\%-coal B 25\% & 7.265 & 27.76 & 13.76 & 48.78 \\
Faxinal 50\%-coal B 50\% & 0.12 & 23.15 & 11.76 & 59.97 \\
Faxinal 25\%-coal B 75\% & 3.30 & 21.88 & 9.80 & 65.02 \\
\hline
\end{tabular}

Table 3. Ash chemical composition of Faxinal, A and B coals.

\begin{tabular}{lccc}
\hline Sample & Faxinal & Coal A & Coal B \\
\hline$\%$ Ash & 17.00 & 6.91 & 7.61 \\
$\mathrm{SiO}_{2}$ & 70.00 & 42.30 & 44.67 \\
$\mathrm{Al}_{2} \mathrm{O}_{3}$ & 19.00 & 41.0 & 24.68 \\
$\mathrm{Fe}_{2} \mathrm{O}_{3}$ & 5.60 & 5.04 & 7.78 \\
$\mathrm{MnO}$ & n.d. & 0.04 & 0.03 \\
$\mathrm{MgO}$ & 0.44 & 0.60 & 1.27 \\
$\mathrm{CaO}$ & 1.10 & 1.43 & 9.90 \\
$\mathrm{Na}{ }_{2} \mathrm{O}$ & 0.10 & 0.34 & 0.93 \\
$\mathrm{~K}_{2} \mathrm{O}$ & 1.20 & 2.18 & 0.80 \\
$\mathrm{TiO}_{2}$ & 1.40 & n.d. & n.d. \\
$\mathrm{P}_{2} \mathrm{O}_{5}$ & 0.05 & 1.84 & 1.55 \\
\hline
\end{tabular}

n.d. $=$ not determined

Table 4. Petrography analysis: macerals groups and vitrinite reflectance for Faxinal, A and B coals.

\begin{tabular}{|c|c|c|c|c|c|c|}
\hline \multirow[t]{2}{*}{ Sample } & \multirow[t]{2}{*}{ Vitrinite } & \multirow[t]{2}{*}{ Liptinite } & \multicolumn{2}{|c|}{ Inertinite } & \multirow[t]{2}{*}{ Minerals } & \multirow[t]{2}{*}{ Ro $(\%)$} \\
\hline & & & $\begin{array}{l}\text { Semi- } \\
\text { fusinite }\end{array}$ & Others & & \\
\hline Faxinal & 91.0 & 4.4 & 0.4 & 4.2 & 10.4 & 0.48 \\
\hline Coal A & 51.8 & - & 27.2 & 21.0 & 1.0 & 1.58 \\
\hline Coal B & 58.2 & - & 29.6 & 12.2 & 1.8 & 1.68 \\
\hline
\end{tabular}

Others = fusinite, micrinite, macrinite, funginite and inertodetrinite.

\subsection{Evaluation of coals and coal blends reactivity}

With relation to the graph shown in Figure 2, the first loss of mass refers to the pyrolysis and occurs in the $350-770{ }^{\circ} \mathrm{C}$ range for the Faxinal coal and in the $500-900{ }^{\circ} \mathrm{C}$ range for the coals A and $\mathrm{B}$. The difference in the temperature ranges at which the pyrolysis occurs is 
due to the samples different degrees of carbonification. The second loss of mass starts at about 40 minutes after the pyrolysis and it refers to the consumption of the fixed carbon by $\mathrm{CO}_{2}$.

The mass stabilization that indicates the end of the reaction in the isotherm time (1 hour) does not occur. Actually, the stabilization occurs approximately after 4 and a half hours of isotherm, when the coal A achieves $98 \%$ of conversion. Coal B, similarly to the coal A, reached $97 \%$ of conversion in 4 hours 30 minutes.

Table 5 presents the values for the maximum reaction rate, time spent until the attainment of the maximum reaction rate and time until the $50 \%$ conversion for the individual coals and their blends. The highest conversion reached by the Faxinal coal is explained by its lower rank and also it can be related to its petrographical composition, mainly with the high vitrinite content. Vitrinite is considered a very reactive component, when compared to inertinite. Inertinite is composed by condensed aromatic nuclei, being the densest, poorest in volatiles and less reactive. The imported coals $\mathrm{A}$ and $\mathrm{B}$ have high contents of inertinite and a high rank This explains their low degree of conversion ${ }^{2}$.

In accordance with $\mathrm{Lu}^{5}$, because of the particle size used in PCI, the reaction rate can be affected by the intrinsic reactivity (determined by the chemical structure). The behavior of the Faxinal coal, coal A and the mixtures in the time of 20 minutes isotherm are shown in Figure 3. This time interval was chosen because it is approximately the time the Faxinal coal takes to complete its gasification.

It is noticed from Figure 3 that the Brazilian coal reaches greater conversions values in significantly lesser times that the others. Moreo-

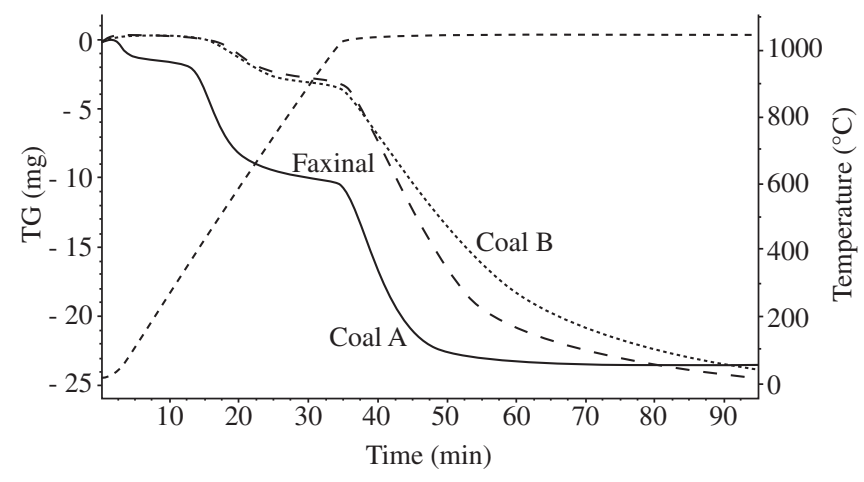

Figure 2. Thermogravimetric analysis for Faxinal coal, coals A and B. ver, the bigger the proportion of this coal in the mixtures, the faster these blends reach bigger conversions. Initially the differences are more significant but, as time passes, the conversion increases and the reaction rate diminishes ${ }^{13}$. Then, the reactivity decreases and these differences can not be easily evidenced.

In the isotherm time, the conversion for the Faxinal coal was $100 \%$, with a maximum reaction rate of $0.07 \mathrm{~min}^{-1}$, after 4 minutes. For coals $\mathrm{A}$ and $\mathrm{B}$, the maximum reaction rate values were 0.031 and $0.035 \mathrm{~min}^{-1}$, after 10 and 9 minutes, respectively. The reached conversions were 0.82 and 0.84 , respectively. The mixtures had their reactivity evaluated in the same way.

According to Ollero $^{14}$, since the reaction conditions are fixed (for example, temperature, pressure and reactants), the reactivity can have its variation evaluated by the conversion or the time. So, to comparing the time where definitive conversion is reached would be a suitable tool to determine a representative value of reactivity ${ }^{13}$. In the present study, the time that the samples take to reach a $50 \%$ conversion was chosen (Table 5).

A statistical method to evaluate the reactivity differences among the coals and the mixtures was done. The results of the analysis of variance (ANOVA) can be summarized as follow:

- Time to reach the maximum rate were quite different for Faxinal and coals $\mathrm{A}$ and $\mathrm{B}$. Faxinal reached the maximum reaction rate in about half of the time;

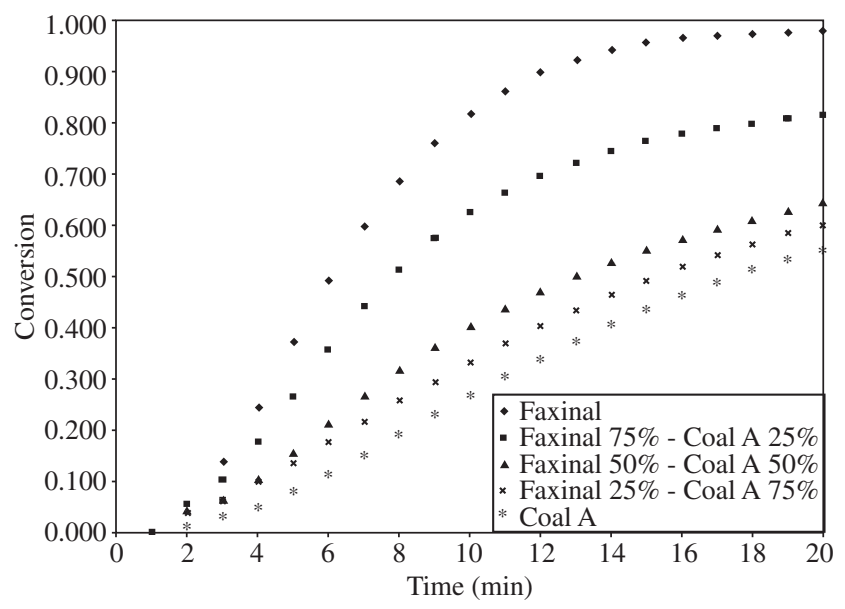

Figure 3. Conversion up to 20 minutes isotherm for Faxinal coal, coal A and their mixtures.

Table 5. Maximum reaction rate, time spent until the attainment of the maximum reaction rate and time until the 50\% conversion for the individual coals and their mixtures.

\begin{tabular}{lccc}
\hline \multicolumn{1}{c}{ Sample } & Maximum reaction rate $\left(\mathrm{min}^{-1}\right)$ & $\begin{array}{c}\text { Time until the maximum } \\
\text { reaction rate (min) }\end{array}$ & $\begin{array}{c}\text { Time until a 50\% } \\
\text { conversion (min) }\end{array}$ \\
\hline Faxinal & 0.071 & 4.0 & 6.0 \\
Faxinal 75\%-Coal A 25\% & 0.063 & 5.0 & 7.5 \\
Faxinal 50\%-Coal A 50\% & 0.043 & 7.5 & 13.0 \\
Faxinal 25\%-Coal A 75\% & 0.036 & 8.5 & 16.0 \\
Coal A & 0.035 & 10 & 17.0 \\
Faxinal 75\%-Coal B 25\% & 0.059 & 5.0 & 8.0 \\
Faxinal 50\%-Coal B 50\% & 0.042 & 7.5 & 14.0 \\
Faxinal 25\%-Coal B 75\% & 0.031 & 8.5 & 16.0 \\
Coal B & 0.031 & 9 & 18.0 \\
\hline
\end{tabular}


- Amount of Faxinal in the mixtures influenced the time in which the maximum reaction rate was attained;

- Higher Faxinal proportion in the mixture faster the maximum reaction rate in the gasification is reached;

- There were significant differences between the time to reach the maximum rate for a $50 \%$ conversion either for the individual coals and for the mixtures.

- Proportion of Faxinal coal in the mixture influences the time necessary for the $50 \%$ conversion; and

- In the case of coal mixtures, the necessary time for $50 \%$ conversion decreases as the proportion of Faxinal coal increases.

The reactivity of unburned char is relevant for the combustion in blast furnace ${ }^{4}$. The most reactive a char is, the best is its effect in the replacement of the coke ${ }^{2}$. The faster the burning occurs in the conditions of the tuyere and the following gasification, the better ${ }^{17}$.

\section{Conclusions}

The main experimental results obtained in this study are showed bellow:

- Additive behavior of the mixtures is true for volatile matter and ashe contents in coal, alkalis and phosphorus contents in ash, as well as reactivity;

- According to the characteristics of the coals used for PCI, the mixture containing 50\% Faxinal and 50\% coal A is indicated for further tests in the industrial process;

- Faxinal coal presents a reactivity superior to that of the imported A and B coals;

- Burn-off time of Faxinal coal gasification reaction is approximately 15 times lower than that for the imported ones; and

- The reactivity increase with Faxinal coal content in the mixtures. The time to reach the maximum rate and the $50 \%$ conversion decreases as the content of Faxinal in the mixtures increases.

\section{Acknowledgments}

The authors are thankful to the support given by the $\mathrm{CNPq}$ COPELMI and the USIMINAS Research Center.

\section{References}

1. Carneiro RTS, Castro JB. Otimização da injeção de combustíveis nos altos fornos da Usiminas com o uso de misturas de carvões. In: Proceedings of XXXI Seminário de Redução de Minério de Ferro da ABM; 2000; Santos, Brazil. São Paulo, ABM; 2000. p. 589-603.
2. Crelling JC. Coal combustion under conditions of blast furnace injection. In: Ironmaking Conference Proceedings; 1995, Nashville, U.S.A Warrendale, U.S.A, ISS; 1995. p. 73-79.

3. Kalkreuth W, Borrego AG, Alvarez D, Menendez R, Osório E, Ribas M, Vilela ACF, Cardozo AT. Exploring the possibilities of using Brazilian subbituminous coals for blast furnace pulverized fuel injection. Fuel. 2005; 84(6):763-772

4. Hutny WP, Giroux L, MacPhee JA, Price JT. Quality of coal for blast furnace injection. In: Proceedings of Blast Furnace Injection Symposium; Cleveland, Ohio; 1996, p. 1-31.

5. Lu L, Sahajwalla V, Chunhau K, Mclean A. Chemical structure of chars prepared under conditions prevailing in the blast furnace PCI operation. ISIJ International. 2002; 42(8):8816-825.

6. Naruse I, Inada T. Characteristics of pulverized coal combustion. In: Ishii K, editor. Advanced pulverized coal injection technology and blast furnace operation. Netherlands: Pergamon; 2000. p. 15-34.

7. Ottaway M. Use of thermogravimetric for proximate analysis of coals and cokes. Fuel. 1982; 61(8):713-716.

8. Schütte K, Rotzoll G, Schügerl K. Simultaneous measurement of weight loss by DTG combustion and $\mathrm{SO}_{2}$-formation for different coals. Fuel. 1989; 68(12):1603-1605.

9. Morgan PA, Robertson SD, Unsworth JF. Combustion studies by thermogravimetric analysis. Fuel. 1986; 65(11):1546-1551.

10. Gomes MLI, Osório E, Vilela ACF. Estudos preliminares da viabilidade técnica da utilização de carvões gaúchos para PCI. In: XXIII Seminário de Redução de Minério de Ferro da ABM; 2002, Vitória, Brazil. São Paulo, ABM: 2002. p. 209 -217.

11. Zolin A, Jenser A, Pedersen LS, Dam-Johansen K. A comparison of coal char reactivity determined from thermogravimetric and laminar flow reactor experiments. Energy \& Fuels. 1998; 12(2): 268-276.

12. Shaw KJ, Beamish BB, Rodgers KA. Thermogravimetric analytical procedures for determining reactivities of chars from New Zealand coals. Thermochimica Acta. 1997; 302(1-2): 181-187.

13. Liliedahl T, Sjöstrom K. Moddeling of char-gas reaction kinetics. Fuel. 1997; 76(1):29-37.

14. Ollero P, Serrera A, Arjona R, Alcantarilla S. Diffusional effects in TGA gasification for kinetic evaluation. Fuel. 2002; 81(14):1989-2000.

15. Levenspiel O. Chemical Reaction Engineering. $3^{\text {rd }}$ ed. New York: John Wiley \& Soons; 1999.

16. Molina A, Mondragón F. Reactivity of coal gasification with steam and CO . Fuel. 1998; 77(15):1831-1839.

17. Kamijou T, Shimizu M. PC combustion in blast furnace. In: Ishii K, editor. Advanced pulverized coal injection technology and blast furnace operation. Netherlands: Pergamon; 2000. p. 63-82. 